\title{
The Influence Of Health Education To Parents Through The Children With Hand Puppets And Comic Strip On Knowledge Of Healthy Latrine Use
}

\author{
M. Fajriannor $\mathrm{TM}^{1} *$ \\ ${ }^{1}$ Sari Mulia School of Health Science, Banjarmasin, Indonesia \\ m.fajriannor.tm@stikessarimulia.ac.id
}

Fauji Nurdin ${ }^{2}$

Sari Mulia Midwifery Academy

fauzi_nurdin@akbidsarimulia.ac.id

\section{Husnul Khotimah ${ }^{2}$}

${ }^{2}$ School of Public Health, Medicine Faculty Lambung Mangkurat University, Banjarbaru, Indonesia husnulkhotimah1707@gmail.com

\author{
Husda Oktavianor ${ }^{2}$ \\ ${ }^{2}$ School of Public Health, Medicine Faculty Lambung Mangkurat University, Banjarbaru, Indonesia \\ husda.oktavianoor@gmail.com
}

\begin{abstract}
Objective: The purpose of this study was to analyze the influence of health education given to parents through the child about knowledge, attitudes, and practices the healthy latrine use in the public health center of Dalam Pagar.

Method: This study used quantitative methods, and the type of research is queasy experimental with non-equivalent control group design. Samples are chosen using a purposive sampling technique, which consisted of 40 peoples which are divided into 20 people in the treatment group and the control group.

Results: The results showed differences in knowledge of healthy latrine usage between before and after the given health education (p-value: 0,013), where an increase in knowledge in the treatment group is higher than the control group.

Conclusion: Health education is given to parents through the child have received in the form of health education use hand puppets and media health promotion in the form of comic strips in local language increase knowledge of healthy latrine usage.
\end{abstract}

Keywords: Comicstrip, Hand puppets, Health Education, Healthy Latrine, and Knowledge.

\section{INTRODUCTION}

Adequate sanitation is a necessary prerequisite for improving the health standards generally, improving labor productivity and improving quality of life. Have adequate sanitation facilities in terms of hygiene including the use of latrines, cleanliness of the surrounding environment, solid and liquid waste disposal and hygiene behavior can improve health and prosperous [1].

Inadequate sanitation has a direct effect on the health of individuals, families, communities and the nation as a whole [2]. Every 20 seconds, a child in the world dies because of the poor sanitation [3]. About $80 \%$ of all diseases in developing countries are associated with unclean water and inadequate 
sanitation. $5.3 \%$ of all deaths and $6.8 \%$ of all disabilities in the world are caused by poor sanitation and unclean water [4].

The data from rural sanitation studies and surveys in Indonesia show that rural households which actually have access to healthy latrines are very few. Only $37 \%$ of the rural population have access to adequate sanitation according to the Join Monitoring Program report. Poor sanitation is one of the causes of child mortality under 3 years of $19 \%$ or about 100,000 children die from diarrhea every year [5].

In Indonesia, diarrhea is the leading cause of death of infants aged 0-12 months. National data of Ministry of Health mentioned that every year in Indonesia 100,000 children dies because of diarrhea. That means every day there are 273 children who died in vain, equal to 11 souls died every hour or 1 soul died every 5.5 minutes due to diarrhea [6]. Data in 2013 indicates that the percentage of the population for proper sanitation in South Kalimantan is at the bottom 3 of the other provinces, which is only $35.14 \%$. The geographical condition of South Kalimantan, which is largely a swamp and waters area, also plays a role in determining the percentage of households according to access to proper disposal of feces according to the MDGs, where the national average indicates $55.5 \%$, while South Kalimantan is still at $50.9 \%$ [7].

The incidence of diarrhea in Banjar Regency until 2013 is still very high when compared to other districts in South Kalimantan which is 9,920 cases. The incidence of diarrhea also shows cases increasing, in the last 3 years as many as 1711 cases. In 2011 as many as 8,209 cases, in 2012 as many as 9650 cases. One of the Puskesmas that has the highest case of diarrhea and continues to showcase increasing is Puskesmas Dalam Pagar. In 2011 as many as 520 cases, in 2012 as many as 919 cases, and in 2013 as many as 1,141 cases. The incidence of diarrhea from January to October 2014 at the public health center has reached 879 cases, and $76 \%$ of diarrhea cases in Puskesmas Dalam Pagar is male [8].

There is still a perception in the Puskesmas Pagar Dalam area about diarrhea. From the results of interviews with mothers in the Puskesmas Dalam Pagar area, their diarrhea-affected children are considered as a natural thing that is part of a child's growth such as crawling and walking. Another thing to support is the environmental conditions that are on the Riverside [9]. Health education in the elderly through the children is reported can increase knowledge, attitudes, and precautions significantly [10]. Health education in primary school-aged children as agents of change in their environment requires an approach that the children like, such as games, discussions, and simulations presented in an interesting manner [11]. 


\section{METHOD AND PROCEDURES}

This research is a quantitative research with quasi-experimental research method with nonequivalent control group design. The sample of this study were parents of SDN Melayu and SDN Melayu Tengah class 4 and 5 students whose children were still recorded as the active students when the research was conducted and in the latrine disposal behavior double access both at home and riverside latrine. In a simple experimental study using the treatment group and the control group, the sample of each group was between 10 - 20 (Sugiyono, 2002). Knowledge, attitude, and practice are measured 3 times before pretest, 2 weeks after intervention (posttest 1), and 1 month after intervention (posttest 2). Statistical analysis used was univariate and bivariate with a paired t-test and independent t-test if the data were normally distributed. If the data is not normally distributed, then the test of Wilcoxon and u-Mann Withney [12].

\section{RESULT}

Prior to the intervention, data was collected included the age and education of respondents. Further measurement of knowledge about the use of healthy latrine before and after the intervention.
Table 1 Distribution Frequency of Respondents Based on Age

\begin{tabular}{|c|c|c|c|c|c|c|}
\hline \multirow[t]{2}{*}{ Age } & \multicolumn{2}{|c|}{$\begin{array}{l}\text { Treatme } \\
\text { nt Group }\end{array}$} & \multicolumn{2}{|c|}{$\begin{array}{l}\text { Control } \\
\text { Group }\end{array}$} & \multirow[t]{2}{*}{$\mathrm{P}$} & \multirow{2}{*}{$\begin{array}{c}\text { Informati } \\
\text { on }\end{array}$} \\
\hline & $\mathrm{F}$ & $\%$ & $\mathrm{~F}$ & $\%$ & & \\
\hline$<45$ & 12 & 60 & $\begin{array}{l}1 \\
4\end{array}$ & 70 & \multirow{3}{*}{$\begin{array}{c}0,35 \\
6\end{array}$} & \multirow{3}{*}{$\begin{array}{c}\text { There is } \\
\text { no } \\
\text { difference }\end{array}$} \\
\hline $\begin{array}{c}\text { yo } \\
>45 \\
\text { yo }\end{array}$ & 8 & 40 & 6 & 30 & & \\
\hline $\begin{array}{c}\text { Tota } \\
1\end{array}$ & 20 & 100 & $\begin{array}{l}2 \\
0\end{array}$ & $\begin{array}{c}10 \\
0\end{array}$ & & \\
\hline
\end{tabular}

The result of statistic test of u-Mann Whitney got $\mathrm{p}$-value $=0,356(>0,05)$ so it can be concluded that there is no difference of age of respondent in treatment group and control group. According to Notoatmodjo (2010) mentions that age is the length of life calculated from birth. The more people age, the more their responsiveness. Through the journey of age, the more mature individuals will adapt behavior to the environment. In L. Green's theory also states that age is one of the factors that facilitate and underlie for the occurrence of the behavior. This statement shows that the age of the respondents who are more mature will easily adapt to the surrounding environment where they want to follow the behavior in terms of sanitation, due to the influence of the surrounding environment such as exposure to information resources, family support, and experience that will increase in line with the increased age [13]. 
Table 2 Distribution Frequency of

Respondents Based on Education

\begin{tabular}{|c|c|c|c|c|c|c|}
\hline \multirow[t]{2}{*}{$\begin{array}{c}\text { Educati } \\
\text { on }\end{array}$} & \multicolumn{2}{|c|}{$\begin{array}{c}\text { Treatme } \\
\text { nt } \\
\text { Group }\end{array}$} & \multicolumn{2}{|c|}{$\begin{array}{c}\text { Contro } \\
1 \\
\text { Group }\end{array}$} & \multirow[t]{2}{*}{$\mathrm{P}$} & \multirow[t]{2}{*}{$\begin{array}{c}\text { Informat } \\
\text { ion }\end{array}$} \\
\hline & $\mathrm{F}$ & $\%$ & $\mathrm{f}$ & $\%$ & & \\
\hline $\begin{array}{c}\text { SD / } \\
\text { MI }\end{array}$ & 9 & 45 & $\begin{array}{l}1 \\
2\end{array}$ & 60 & & \\
\hline $\begin{array}{l}\text { SMP / } \\
\text { Mts }\end{array}$ & 8 & 40 & 6 & 30 & 0,35 & $\begin{array}{c}\text { There is } \\
\text { no }\end{array}$ \\
\hline $\begin{array}{c}\text { SMA / } \\
\text { Ma }\end{array}$ & 3 & 15 & 2 & 10 & 2 & $\begin{array}{c}\text { differenc } \\
\text { e }\end{array}$ \\
\hline Total & 20 & $\begin{array}{c}10 \\
0\end{array}$ & $\begin{array}{l}2 \\
0\end{array}$ & $\begin{array}{c}10 \\
0\end{array}$ & & \\
\hline
\end{tabular}

Test of $u$-Mann Whitney.

The result of the statistical test of $\mathrm{u}$ Mann Whitney got p-value $=0,352(>0,05)$ so it can be concluded that there is no difference of respondent education in treatment group and control group. Education is assumed to be related to knowledge, this statement is in line with the theory that a highly educated person will have a better knowledge than a low level of education. The higher the education of a person then they will be more easily to receive information and solve new things [14]

Table 3 Score Distribution of Respondents Knowledge about The Use of Latrine Prior to Intervention (Pretest)

\begin{tabular}{|c|c|c|c|c|}
\hline Value & $\begin{array}{c}\text { Treatme } \\
\text { nt } \\
\text { Group }\end{array}$ & $\begin{array}{l}\text { Contr } \\
\text { ol } \\
\text { Grou } \\
p\end{array}$ & $\mathrm{P}$ & $\begin{array}{c}\text { Informati } \\
\text { on }\end{array}$ \\
\hline Mean & 29,50 & 30,00 & \multirow{4}{*}{$\begin{array}{c}0,80 \\
7\end{array}$} & \multirow{4}{*}{$\begin{array}{c}\text { There is } \\
\text { no } \\
\text { differenc } \\
\mathrm{e}\end{array}$} \\
\hline Median & 30,00 & 30,00 & & \\
\hline $\begin{array}{l}\text { Minimu } \\
\mathrm{m}\end{array}$ & 16 & 24 & & \\
\hline $\begin{array}{l}\text { Maximu } \\
\mathrm{m}\end{array}$ & 37 & 37 & & \\
\hline
\end{tabular}

Test of $u$-Mann Whitney.
The result of the statistical test of $\mathrm{u}$ Mann Whitney got p-value $=0,807(>0,05)$ so it can be concluded that there is no difference of respondent knowledge in treatment group and control group before given intervention (pretest). The absence of different knowledge of respondents in both groups before being given intervention is an advantage in this study because respondents have relatively the same knowledge about the use of healthy latrines.

Table 4 Score Distribution of Respondents Knowledge about The Use of Healthy Latrine 2 Weeks After Intervention (Posttest 1)

\begin{tabular}{|l|c|c|c|c|}
\hline Value & $\begin{array}{c}\text { Treat } \\
\text { ment } \\
\text { Group }\end{array}$ & $\begin{array}{c}\text { Con } \\
\text { trol } \\
\text { Gro } \\
\text { up }\end{array}$ & $\mathrm{P}$ & $\begin{array}{c}\text { Inform } \\
\text { ation }\end{array}$ \\
\cline { 1 - 3 } Mean & 33,50 & $\begin{array}{c}30,5 \\
0\end{array}$ & & \\
\cline { 1 - 3 } $\begin{array}{l}\text { Media } \\
\mathrm{n}\end{array}$ & 34,50 & $\begin{array}{c}30,0 \\
0\end{array}$ & 0,0 & $\begin{array}{c}\text { There } \\
\text { is a } \\
\text { differe } \\
\text { nce }\end{array}$ \\
\cline { 1 - 3 } $\begin{array}{l}\text { Mini } \\
\text { mum }\end{array}$ & 26 & 24 & 14 & \\
\cline { 1 - 4 } $\begin{array}{l}\text { Maxi } \\
\text { mum }\end{array}$ & 36 & 36 & & \\
\hline
\end{tabular}

Test of $u$-Mann Whitney.

Hasil uji statistik u-mann whitney didapatkan nilai $\mathrm{p}=0,014(<0,05)$ sehingga dapat disimpulkan bahwa ada perbedaan pengetahuan responden pada kelompok perlakuan dan kelompok kontrol 2 minggu sesudah diberikan intervensi (posttest 1). Adanya perbedaan pengetahuan responden pada kedua kelompok sesudah diberikan intervensi karena adanya intervensi yang berbeda pada kedua kelompok tersebut. 
The result of statistic test of u-Mann Whitney was obtained $\mathrm{p}$-value $=0,014$ $(<0,05)$ so it can be concluded that there is a difference of respondent knowledge in treatment group and control group 2 weeks after giving intervention (posttest 1). There was a difference of respondent knowledge in both groups after being given intervention because of different intervention in both groups.

Table 5 Score Distribution of Respondents Knowledge about The Use of Healthy Latrine 1 Month After Intervention (Posttest 2)

\begin{tabular}{|c|c|c|c|c|}
\hline Value & $\begin{array}{l}\text { Treatm } \\
\text { ent } \\
\text { Group }\end{array}$ & $\begin{array}{c}\text { Contr } \\
\text { ol } \\
\text { Grou } \\
p\end{array}$ & $\mathrm{P}$ & $\begin{array}{l}\text { Informati } \\
\text { on }\end{array}$ \\
\hline Mean & 34,35 & 30,60 & \multirow{4}{*}{$\begin{array}{c}0,00 \\
01\end{array}$} & \multirow{4}{*}{$\begin{array}{c}\text { There is } \\
\text { a } \\
\text { differenc } \\
\text { e }\end{array}$} \\
\hline Median & 34,50 & 31,00 & & \\
\hline $\begin{array}{l}\text { Minimu } \\
\mathrm{m}\end{array}$ & 29 & 24 & & \\
\hline $\begin{array}{l}\text { Maxim } \\
\text { um }\end{array}$ & 38 & 37 & & \\
\hline
\end{tabular}

Test of the independent t-test.

The result of independent t-test statistic is $\mathrm{p}$-value $=0.0001(<0,05)$ so it can be concluded that there is a difference of respondent knowledge in treatment group and control group 1 month after given intervention (posttest 2). There was a difference of respondent knowledge in both groups after being given intervention because of different intervention in both groups.
Table 6 The Differences of Knowledge Score of Respondents Before and 2 Weeks After Intervention

\begin{tabular}{|c|c|c|c|c|}
\hline \multirow[t]{2}{*}{ Group } & \multicolumn{2}{|c|}{ Mean } & \multirow[b]{2}{*}{$P$} & \multirow[b]{2}{*}{$\begin{array}{l}\text { Informati } \\
\text { on }\end{array}$} \\
\hline & $\begin{array}{l}\text { Prete } \\
\text { st }\end{array}$ & $\begin{array}{l}\text { Postte } \\
\text { st } 1\end{array}$ & & \\
\hline $\begin{array}{l}\text { Treatme } \\
\mathrm{nt}\end{array}$ & 29,50 & 33,50 & $\begin{array}{l}0,01 \\
3^{\mathrm{a}}\end{array}$ & $\begin{array}{l}\text { There is a } \\
\text { difference }\end{array}$ \\
\hline Control & 30,00 & 30,50 & $\begin{array}{l}0,12 \\
6^{b}\end{array}$ & $\begin{array}{l}\text { There is } \\
\text { no } \\
\text { difference }\end{array}$ \\
\hline
\end{tabular}

Paired t-test

Wilcoxon statistic test results in the treatment group got $\mathrm{p}$-value $=0.013(<0.05)$, so it can be concluded that there are differences of knowledge before and 2 weeks after being given intervention in the treatment group. In the control group, $\mathrm{p}$-value $=0.126$ (>0.05), so it can be concluded that there is no difference of knowledge before and 2 weeks after intervention.

Table 7 The Differences of Knowledge Score of Respondents Before and 1 Month After Intervention

\begin{tabular}{|c|c|c|c|c|}
\hline \multirow[t]{2}{*}{ Group } & \multicolumn{2}{|c|}{ Mean } & \multirow[b]{2}{*}{$\mathrm{P}$} & \multirow[b]{2}{*}{$\begin{array}{c}\text { Informati } \\
\text { on }\end{array}$} \\
\hline & $\begin{array}{l}\text { Prete } \\
\text { st }\end{array}$ & $\begin{array}{l}\text { Postte } \\
\text { st } 2\end{array}$ & & \\
\hline $\begin{array}{l}\text { Treatme } \\
\mathrm{nt}\end{array}$ & 29,50 & 34,35 & $\begin{array}{l}0,00 \\
4\end{array}$ & $\begin{array}{l}\text { There is a } \\
\text { difference }\end{array}$ \\
\hline Control & 30,00 & 30,60 & $\begin{array}{l}0,11 \\
0\end{array}$ & $\begin{array}{l}\text { There is } \\
\text { no } \\
\text { difference }\end{array}$ \\
\hline
\end{tabular}

\section{Paired t-test}

The result of paired t-test in the treatment group got $\mathrm{p}$ value $=0,004(<0,05)$, so it can be said there is a difference of 
knowledge before and 1 month after giving intervention in the treatment group. In the control group, based on paired t-test statistic test, $\mathrm{p}$-value $=0,110(>0,05)$, so there is no difference of knowledge before and 1 month after intervention.

Table 8 The Difference of Score Respondents Knowledge 2 Weeks and 1 Month After Intervention

\begin{tabular}{|c|c|c|c|c|}
\hline \multirow{2}{*}{$\begin{array}{l}\text { Grou } \\
\mathrm{p}\end{array}$} & \multicolumn{2}{|c|}{ Mean } & \multirow[b]{2}{*}{$\mathrm{P}$} & \multirow[b]{2}{*}{$\begin{array}{c}\text { Inform } \\
\text { ation }\end{array}$} \\
\hline & $\begin{array}{l}\text { Post } \\
\text { test } \\
1\end{array}$ & $\begin{array}{l}\text { Post } \\
\text { test } \\
2\end{array}$ & & \\
\hline $\begin{array}{l}\text { Treat } \\
\text { ment }\end{array}$ & $\begin{array}{l}33,5 \\
0\end{array}$ & $\begin{array}{l}34,3 \\
5\end{array}$ & $\begin{array}{l}0,0 \\
48^{\mathrm{a}}\end{array}$ & $\begin{array}{l}\text { There } \\
\text { is a } \\
\text { differe } \\
\text { nce }\end{array}$ \\
\hline $\begin{array}{l}\text { Contr } \\
\text { ol }\end{array}$ & $\begin{array}{l}30,5 \\
0\end{array}$ & $\begin{array}{l}30,6 \\
0\end{array}$ & $\begin{array}{l}0,8 \\
34^{b}\end{array}$ & $\begin{array}{l}\text { There } \\
\text { is no } \\
\text { differe } \\
\text { nce }\end{array}$ \\
\hline
\end{tabular}

Paired t-test

The result of Wilcoxon statistic test in the treatment group got $\mathrm{p}$-value $=0,048$ $(<0,05)$, so it can be said there is a difference of knowledge 2 weeks after intervention and 1 month after given intervention in the treatment group. In the control group, p-value $=0.834(>0,05)$, so it can be said that there is no difference of knowledge 2 weeks after intervention and 1 month after intervention.

\section{IV.DISCUSSION}

Health counseling given to parents through children in this research is delivered by telling stories using hand puppets. The concept of health counseling given because the target is the students of grade 4 and 5 where at this time students have been able to think about the concept of time and remember the events of the past and realized the activities performed repeatedly, but the understanding is not deep, will further develop at the end of age school or early adolescence, and will be the agent of change in the environment [15].

Elementary students who have received training are given the task to convey health information to parents at home. In the intervention group, parents get health education through elementary students who are also equipped with picture books. This illustrated storybook contains information about unhealthy defecation habits, human germs that are dirt, the flow of disease from human feces to cause pain. Other information that is also presented is the reason why defecation in a riverside latrine is unhealthy, the reason for the use of healthy latrines, and the requirements of healthy latrines.

In the intervention process, students have a role as informants about the use of healthy latrines to parents who were previously obtained during training in their respective schools. This information is given in the morning and afternoon for 1 month. The second time election is because parents are more exposed to their children closely, especially in sanitation practices at home. Every 3 days, students are required to report the activities they do in the process of providing information to teachers in schools who have been appointed as supervisors. 
A good health promotion media is a media that can deliver health messages to the target according to the needs of the target itself. The selected media is a picture storybook using local language. The reason for choosing this media is because this pocketbook is practically brought at any time, allowing it to be read over and over again by any goal. Based on research on booklet and leaflet by Marlina et al (2009) has proven that media of communication in the form of print media very effective in improving knowledge and change attitude target.

Knowledge is the result of knowing and this happens after people have sensed a particular object. Knowledge generally comes from experience, can also be obtained from information submitted by others, obtained from books, or mass media and electronics. Knowledge can be gained from direct experience or through the experience of others. Knowledge can be enhanced through counseling, either individually or in groups, to improve health knowledge aimed at achieving changes in individual, family, and community behaviors in order to achieve optimum health status [14].

Based on the results of the research, the level of knowledge about the use of latrines increased the correct answer in the treatment group, this means that health education intervention in the form of counseling using hand puppet stories and giving picture books given to elementary students very influential on the level of parental knowledge of the importance of health in particular in the use of healthy latrines. Thus giving an indication that if given a health education about the use of latrines in primary school-aged children then knowledge on students and information to be submitted to parents in this case knowledge will also increase [16].

In addition to using extension methods, the treatment groups in this study also used picture books. After the treatment in the form of health education both counseling and picture book then most of the questions have increased the score after being given treatment. This is in accordance with research conducted by Meena Siwach (2009) that health education can improve both knowledge and attitude about personal hygiene in children [17]. The same thing is also shown in Damayanti's research (215) about the influence of leaflets using local languages [18].

\section{CONCLUSION}

The health education provided in this study increased the average knowledge of 4.85 . Health education intervention in the form of counseling using hand puppet story and giving of comics given to elementary school students is very influential on the level of parental knowledge about the importance of health especially in the use of healthy toilet ( $p$ $=0,013)$. 


\section{REFERENCES}

[1]. Dwivedi P and Sharma AN. A Study on Environmental Sanitation, Sanitary Habits, and Personal Hygiene among the Baigas of Samnapur Block of Dindori District, Madhya Pradesh. Journal of Human Ecology. 2007; 1(1) :7-10.

[2]. World Health Organization. Environmental Sanitation Guidelines, Rural Village Water Resources Management Project. WHO. Geneva. 2009.

[3]. WHO and UNICEF. Joint Monitoring Programme on Water Supply and Sanitation and Water Supply and Sanitation Collaborative Council. WHO and UNICEF. Geneva. 2012.

[4]. Thapa M. and Sharma AP. Study of Bacteriological Treatment of Water for Rural Communities Nepal. Journal of Science and Technology. Royal Nepal; Academy of Science and Technology. Kathmandu 1999; 1: 27-33.

[5]. Nasili, Thaha RM, dan Seweng A. Perilaku Pencegahan Diare Anak Balita di Wilayah Bantaran Kali Kelurahan Bataraguru Kecamatan Walio Kota BauBau. Universitas Hassanudin. Makassar. 2012.

[6]. Departemen Kesehatan RI. Pedoman Pengelolaan Promosi Kesehatan. Pusat Promosi Kesehatan. Departemen Kesehatan RI. Jakarta. 2007.

[7]. Kementrian Kesehatan RI. Laporan Ringkasan Eksekutif Kalimantan Selatan Tahun 2013. Pusat Data dan Informasi Kementrian Kesehatan RI. Jakarta. 2013.

[8]. Dinas Kesehatan Kabupaten Banjar. Profil Dinas Kesehatan Kabupaten Banjar Tahun 2013. Dinas Kesehatan Kabupaten Banjar. Martapura. 2013.

[9]. UNICEF Indonesia. Air Bersih, Sanitasi, dan Kebersihan. UNICEF Indonesia. Jakarta. 2012.

[10]. Ernawati F. Pengaruh Pendidikan Kesehatan terhadap Peningkatan Pengetahuan tentang Diare pada Anak Jalanan di Semarang. (Karya Tulis Ilmiah). Program Pendidkan Sarjana
Kedokteran. Fakultas Kedokteran. Universitas Diponegoro. Semarang. 2012.

[11]. Effendi, dan Makfudli. Keperawatan Kesehatan Komunitas: Teori dan Praktek dalam Keperawatan. Penerbit Salemba Medika. Jakarta. 2008.

[12]. Dahlan S. Statistik untuk Kedokteran dan Kesehatan Edisi 4. Penerbit Salemba Medika. Jakarta. 2009.

[13]. Green LW, and Kreuter MW, Health Promotion Planning: An Educational dan Environmental Approach. Mayfield Publishing Company. California. 1991.

[14]. Notoatmodjo S. Pendidikan dan Perilaku Kesehatan. Penerbit Rineka Cipta. Jakarta. 2010.

[15]. Fatimah S. Pengaruh Intervensi Promosi Kesehatan terhadap Pengetahuan, Sikap, dan Praktek Perilaku Hidup Bersih dan Sehat Siswa Kelas 4 dan 5 SDN Kembaran Kecamatan Loano Kabupaten Purworejo Propinsi Jawa Tengah. (Skripsi). Prodi Kesehatan Masyarakat. Fakultas Kesehatan Masyarakat Universitas Indonesia. Depok. 2012.

[16]. Hermayan Y, dan Ikhsan KN. Pengaruh Penyuluhan Kesehatan Lingkungan terhadap Tingkat Pengetahuan dan Pelaksanaan Kesehatan Lingkungan SMP Negeri Tambaksari Kecamatan Tambaksari Kabupaten Ciamis. Jurnal Bumi Lestari. 2013; 13(1): 166-173.

[17]. Siwach, M. Impact of Health Education Programme on the Knowledge and Practices of School Children Regarding Personal Hygiene in Rural Panipat. International Journal Science Educational. 2009; 1(2): 115-118.

[18]. Damayanti R. Pengaruh Media Leaflet Berbahasa Daerah terhadap Peningkatan Pengetahuan dan Sikap Ibu tentang Perilaku Hidup Bersih dan Sehat (PHBS) Tatanan Rumah Tangga (ASI Eksklusif) di Kabupaten Sambas. (Tesis). Program Studi Magister Promosi Kesehatan. Fakultas Kesehatan Masyarakat. Universitas Diponegoro. Semarang. 2015. 